Article

\title{
Strategies for Reduced Acid and Metalliferous Drainage by Pyrite Surface Passivation
}

\author{
Gujie Qian ${ }^{1,2, *}$, Russell C. Schumann ${ }^{3}$, Jun Li ${ }^{1}$, Michael D. Short ${ }^{1,2}$, Rong Fan ${ }^{1}$, Yubiao Li ${ }^{1,4}$, \\ Nobuyuki Kawashima ${ }^{2}$, Yan Zhou ${ }^{1}$, Roger St. C. Smart ${ }^{1,5}$ and Andrea R. Gerson ${ }^{5, *}$ \\ 1 Natural and Built Environments Research Centre, School of Natural and Built Environments, University of \\ South Australia, MLK 26, Mawson Lakes, SA 5095, Australia; jun.li@unisa.edu.au (J.L.); \\ Michael.Short@unisa.edu.au (M.D.S.); Rong.Fan@unisa.edu.au (R.F.); yubiao.li@whut.edu.cn (Y.L.); \\ yan.zhou@mymail.unisa.edu.au (Y.Z.); Roger.Smart@unisa.edu.au (R.S.C.S.) \\ 2 Future Industries Institute, University of South Australia, Mawson Lakes, SA 5095, Australia; \\ Nobuyuki.Kawashima@unisa.edu.au \\ 3 Levay and Co. Environmental Services, Mawson Lakes, SA 5095, Australia; Russell.Schumann@unisa.edu.au \\ 4 School of Resources and Environmental Engineering, Wuhan University of Technology, \\ Wuhan 430070, China \\ 5 Blue Minerals Consultancy, Middleton, SA 5213, Australia \\ * Correspondence: gujie.qian@unisa.edu.au (G.Q.); andrea.gerson@bigpond.com (A.R.G.); \\ Tel.: +61-8-8302-5305 (G.Q.); +61-422-112-516 (A.R.G.)
}

Academic Editor: Liliana Lefticariu

Received: 16 December 2016; Accepted: 14 March 2017; Published: 17 March 2017

\begin{abstract}
Acid and metalliferous drainage (AMD) is broadly accepted to be a major global environmental problem facing the mining industry, requiring expensive management and mitigation. A series of laboratory-scale kinetic leach column (KLC) experiments, using both synthetic and natural mine wastes, were carried out to test the efficacy of our pyrite passivation strategy (developed from previous research) for robust and sustainable AMD management. For the synthetic waste KLC tests, initial treatment with lime-saturated water was found to be of paramount importance for maintaining long-term circum-neutral $\mathrm{pH}$, favourable for the formation and preservation of the pyrite surface passivating layer and reduced acid generation rate. Following the initial lime-saturated water treatment, minimal additional alkalinity (calcite-saturated water) was required to maintain circum-neutral $\mathrm{pH}$ for the maintenance of pyrite surface passivation. KLC tests examining natural potentially acid forming (PAF) waste, with much greater peak acidity than that of the synthetic waste, blended with lime $(\approx 2 \mathrm{wt} \%)$ with and without natural non-acid-forming (NAF) waste covers, were carried out. The addition of lime and use of NAF covers maintained circum-neutral leachate $\mathrm{pH}$ up to 24 weeks. During this time, the net acidity generated was found to be significantly reduced by the overlying NAF cover. If the reduced rate of acidity production from the natural PAF waste is sustained, the addition of smaller (more economically-feasible) amounts of lime, together with application of NAF wastes as covers, could be trialled as a potential cost-effective AMD mitigation strategy.
\end{abstract}

Keywords: acid and metalliferous drainage control; kinetic leach columns; pyrite surface passivation; reactive natural mine waste; reduced acid generation

\section{Introduction}

Acid and metalliferous drainage (AMD) from mine wastes is a global environmental issue and remains a costly economic and social challenge for the international mining sector. AMD is primarily caused by the oxidation of sulphide minerals, particularly pyrite (Equations (1) and (2)), and can also contain toxic metal/metalloid ions (e.g., As, $\mathrm{Cd}, \mathrm{Zn}, \mathrm{Pb}$ ) [1,2]. 


$$
\begin{gathered}
\mathrm{FeS}_{2}+3.5 \mathrm{O}_{2}+\mathrm{H}_{2} \mathrm{O} \rightarrow \mathrm{Fe}^{2+}+2 \mathrm{SO}_{4}{ }^{2-}+2 \mathrm{H}^{+} \\
\mathrm{FeS}_{2}+14 \mathrm{Fe}^{3+}+8 \mathrm{H}_{2} \mathrm{O} \rightarrow 15 \mathrm{Fe}^{2+}+2 \mathrm{SO}_{4}{ }^{2-}+16 \mathrm{H}^{+}
\end{gathered}
$$

In principle, a sustainable approach to the management of AMD in pre-planning or during operation should be to exploit, where possible, readily-available, on-site, geochemical and microbiological resources. The approach proposed is to sufficiently reduce the acid generation rate (AGR) so that the neutralisation from on-site non-acid-forming (NAF) materials can be used to match the AGR from waste rock and/or tailings oxidation before final rehabilitation. This matching of AGR to ANR (acid neutralising rate) in kinetically-controlled processes is, in principle, the only viable and sustainable option to achieve long-term mine closure and site relinquishment [3].

Our previous studies have shown that pyrite oxidation rates can be reduced by $50 \%-95 \%$ by the formation and maintenance of continuous amorphous silicate-stabilised iron (oxy)hydroxide pyrite surface layers $[4,5]$. The formation of these layers is achieved by maintaining circum-neutral $\mathrm{pH}$ conditions in the pore water surrounding the pyrite particles in the presence of dissolved silicates, leading to surface layer formation as pyrite oxidation proceeds. These passivating layers can be preserved in a continuous, coherent, and stable form at $\mathrm{pH} \geq 6$. In some cases, the establishment of these stable surface layers may require initial short-term treatment with greater concentrations of alkalinity than those obtained from limestone covers. This is especially the case for semi-arid regions, such as Western Australia's Pilbara region, where alkaline covers are unlikely to succeed as a stand-alone remedy due to the relatively low moisture content and insufficient soluble alkalinity in waste materials. After passivation layers are established, the AGR can be reduced significantly, enabling carbonates (e.g., dolomite, limestone) and some reactive silicates commonly found in waste rocks (e.g., anorthite, feldspar, hornblende) to provide matching ANR [6].

The development of surface passivation, and thus matching of AGR by ANR, forms the fundamental hypothesis of our experimental approach. In this study, we designed two sets of kinetic leach column (KLC) tests using both synthetic and natural mine wastes. This type of KLC setup (Figure 1) or other similar leach columns have been widely used in laboratory AMD studies [3,7-10]. The synthetic waste has a relatively low peak acidity $\left(\approx 2000 \mathrm{mg} \cdot \mathrm{CaCO}_{3} \cdot \mathrm{L}^{-1}\right)$, while the natural, potentially acid forming (PAF) waste has a much greater peak acidity $\left(\approx 20,000 \mathrm{mg} \cdot \mathrm{CaCO}_{3} \cdot \mathrm{L}^{-1}\right)$ as determined from previous KLC tests. For the KLC tests conducted with the synthetic mine waste, our aims were: (1) to verify that initial flushing with lime-saturated water results in circum-neutral $\mathrm{pH}$, which is favourable for the formation of surface passivating layers on pyrite; and (2) to determine the requirement for ongoing alkalinity input (calcite-saturated water) for maintaining circum-neutral $\mathrm{pH}$ conditions in the longer term.

For the natural PAF waste, which had a significantly greater peak acidity than the equivalent alkalinities available from calcite- or even lime-saturated water, we chose to add lime via blending $(\approx 2 \mathrm{wt} \%)$. While lime addition would ideally be much smaller (e.g., $1 \mathrm{t} \cdot$ lime $\cdot \mathrm{kt}^{-1}$ waste, or $\left.0.1 \mathrm{wt} \%\right)$, addition at such small dosages here would provide no more alkalinity than would the addition of lime-saturated water. Therefore, we chose to blend lime at a significantly greater, but likely uneconomic, concentration. The specific aim of our KLC tests using the natural mine wastes was to determine whether blending of lime with and without application of natural NAF top covers could maintain circum-neutral $\mathrm{pH}$ conditions as required for the formation and maintenance of pyrite surface passivation. The formation of these layers would enable the AGR of natural highly-reactive PAF waste materials, such as this natural iron ore PAF waste from the Pilbara region, to be sufficiently attenuated so as to be controlled by alkalinity available from site-derived NAF wastes. 


\section{Materials and Methodology}

\subsection{KLC Tests Using Synthetic Mine Waste}

Four KLC tests (2 kg each) containing synthetic wastes were set up with the same wt \% of mineral components as commonly found in mine wastes: quartz (81.3 wt \%), K-feldspar (10.0 wt \%), chlorite (5.0 wt \%), and pyrite (3.7 wt \%, i.e., 2.0 wt \% S). Quartz, pyrite, K-feldspar, chlorite, and calcite (Geo Discoveries, West Gosford, New South Wales, Australia) were all confirmed by X-ray diffraction (XRD) to have $>90 \mathrm{wt} \%$ purity. Minerals were crushed, pulverised, and dry-sieved to $<4 \mathrm{~mm}$ size for the synthetic waste KLC experiments. The $<4 \mathrm{~mm}$ size fraction allows sufficient material surface exposure to facilitate the dissolution of minerals within acceptable laboratory timescales (from months to years), while providing a sound basis for predicting the field release rates where oxygen availability is not limiting [11].

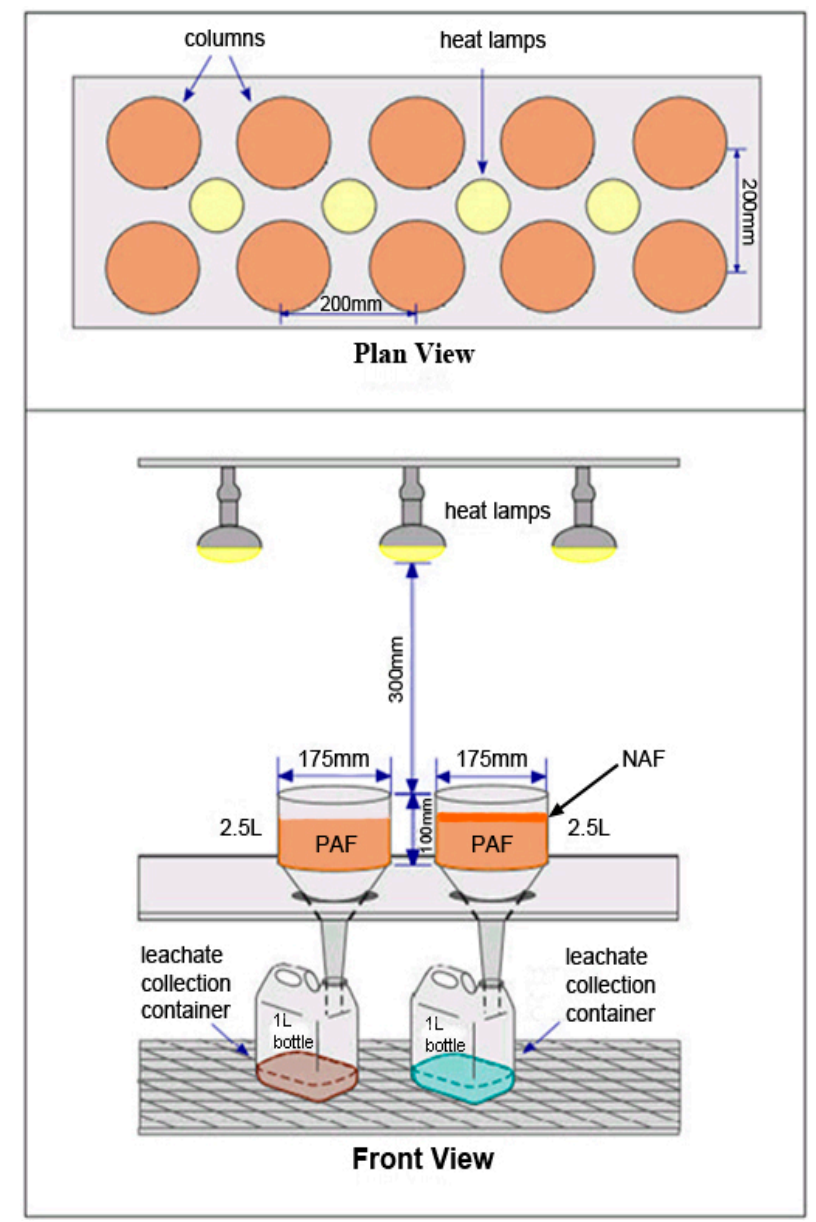

Figure 1. Schematic overview (modified from Figure F1 in [12]) of the KLC setup using conventional Büchner funnels with circular Whatman ${ }^{\circledR}$ cellulose filters $(8 \mu \mathrm{m}$ pore size, provided by Sigma-Aldrich, Castle Hill, Australia) placed at the bottom of the solid wastes. Each synthetic waste KLC contained only PAF material (synthetic mixtures of single minerals including pyrite).

Setup (Figure 1) and daily operation for the synthetic waste KLC tests were, generally, as per [12], except that solutions used for weekly watering $(200 \mathrm{~mL})$ and four-weekly flushing $(800 \mathrm{~mL})$ were varied across KLC tests as defined in Table 1. Watering and flushing were all completed within one minute, but leachate solution collection after flushing took up to $3 \mathrm{~h}$. 
All experiments were carried out under ambient (uncontrolled) laboratory conditions. Heat lamps (100 W incandescent; Figure 1) were used in the last four days ( $4 \mathrm{~h}$ of heating per day) of each weekly cycle to ensure adequate drying of samples between weekly watering/flushing. All KLC tests contained $>20 \mathrm{wt} \%$ water content after each flush but dropped to 2-6 wt \% (synthetic waste) or $2-7 \mathrm{wt} \%$ (natural waste) once heated, as calculated by comparing the wet column weight and the initial dry column weight (NB. wet column weights were obtained immediately prior to watering). Leaching with "wet and dry" cycles provides conditions that approximate those found in the field for an oxygenated zone containing sulphide materials. It was assumed on the basis of previous KLC studies that oxygen was freely available throughout the KLC samples (Sections 2.1 and 2.2) [12,13].

Table 1. Details of KLC setup and watering/flushing protocols (see Supplementary Materials Section S1 for details).

\begin{tabular}{|c|c|c|}
\hline KLC & Watering/Flushing Solution & Watering/Flushing Procedure \\
\hline Control & Milli-Q & Milli-Q for all watering and flushing \\
\hline $\begin{array}{c}\text { Milli-Q with } \\
\text { lime-saturated water }\end{array}$ & $\begin{array}{l}\text { Milli-Q and lime-saturated water } \\
\left(\text { alkalinity } \approx 1900 \mathrm{mg} \cdot \mathrm{CaCO}_{3} \cdot \mathrm{L}^{-1}\right)\end{array}$ & $\begin{array}{l}\text { Milli-Q flush } 0(\text { week } 0) \text {; lime-saturated water } \\
\left(\approx 1900 \mathrm{mg} \cdot \mathrm{CaCO} \mathrm{CO}_{3} \cdot \mathrm{L}^{-1}\right) \text { weeks } 1-3 \text { and flush } 1 \\
(\text { week } 4) ; \text { Milli-Q watering thereafter until } \\
\mathrm{pH}<5.5 \text {, then lime-saturated watering } / \text { flushing } \\
\text { resumed until } \mathrm{pH}>5.5 \text {, after which Milli-Q } \\
\text { watering/flushing until } \mathrm{pH}<5.5\end{array}$ \\
\hline $\begin{array}{l}\text { Calcite-saturated and } \\
\text { lime-saturated water }\end{array}$ & $\begin{array}{l}\text { Calcite-saturated (alkalinity: } \\
\approx 30 \mathrm{mg} \cdot \mathrm{CaCO}_{3} \cdot \mathrm{L}^{-1} \text { ) and } \\
\text { lime-saturated water }\end{array}$ & $\begin{array}{l}\text { Same as for "Milli-Q with lime-saturated water" } \\
\text { KLC except calcite-saturated water used for } \\
\text { watering and flushing from flush } 1 \text { (week } 4 \text { ) }\end{array}$ \\
\hline Calcite-saturated water & Calcite-saturated water & Milli-Q flush 0; calcite-saturated water thereafter \\
\hline
\end{tabular}

\subsection{KLC Tests Using Natural Iron Ore Wastes}

The procedures used for the KLC tests containing natural mine wastes are given in Table 2. The general setup for these KLC experiments is as per Figure 1. However, the amounts of natural wastes used in these tests were reduced due to the limited amount of PAF material available. The volumes of Milli-Q water for watering and flushing were adjusted accordingly, based on the use of $200 \mathrm{~mL}$ $(800 \mathrm{~mL})$ of solutions for weekly watering (and flushing four-weekly) a standard $2 \mathrm{~kg}$ KLC. For all KLC tests using natural wastes, except the test with the natural PAF waste only, lime was blended uniformly with the PAF waste. The amount of lime added to each PAF waste was estimated on the basis of the amount of acidity generated in the initial months from a similar natural PAF mine waste investigated in our previous unpublished work and the pyrite content within the natural PAF waste used in this study.

Table 2. The composition of KLC tests using natural mine waste rock.

\begin{tabular}{|c|c|c|c|}
\hline $\begin{array}{l}\text { Sample } \\
(<4 \mathrm{~mm})\end{array}$ & $\begin{array}{l}\text { Total Sample Weight } \\
\text { Excl. Added Lime (kg) }\end{array}$ & NAF (kg) & KLC Configuration and Operation \\
\hline PAF & 1.45 & 0 & Watering/flushing ${ }^{1}$ as per standard method \\
\hline PAF & $\begin{array}{l}1.45 \text { (blended with } 30 \mathrm{~g} \\
\left.\text { of } \mathrm{Ca}(\mathrm{OH})_{2}\right)\end{array}$ & 0 & Watering/flushing ${ }^{1}$ as per standard method \\
\hline $\begin{array}{l}\text { PAF + NAF1 } \\
\text { top cover }\end{array}$ & $\begin{array}{l}1.75 \text { (blended with } 30 \mathrm{~g} \\
\left.\text { of } \mathrm{Ca}(\mathrm{OH})_{2}\right)\end{array}$ & 0.3 & $\begin{array}{l}\text { NAF added on top of PAF; watering/flushing }{ }^{1} \\
\text { as per standard method }\end{array}$ \\
\hline $\begin{array}{l}\text { PAF + NAF2 } \\
\text { top cover }\end{array}$ & $\begin{array}{l}1.75 \text { (blended with } 30 \mathrm{~g} \\
\left.\text { of } \mathrm{Ca}(\mathrm{OH})_{2}\right)\end{array}$ & 0.3 & $\begin{array}{l}\text { NAF added on top of PAF; watering/flushing }{ }^{1} \\
\text { as per standard method }\end{array}$ \\
\hline
\end{tabular}

${ }^{1}$ Watering and flushing volumes normalised to standard reference KLC sample weight of $2 \mathrm{~kg}$ [12]. 


\subsection{Instrumental Analysis}

Single minerals and natural waste samples were examined using powder X-ray diffraction (XRD, D4 Endeavor diffractometer, Bruker, Billerica, MA, USA) with Co K $\alpha$ radiation $\left(\lambda_{\mathrm{K}_{\alpha 1}}=1.78897 \AA\right.$; $\lambda_{\mathrm{K}_{\alpha 2}}=1.79285 \AA$ ) at $35 \mathrm{kV}$ and $40 \mathrm{~mA}$. Each sample for XRD analysis was dry-ground to a particle size of $<38 \mu \mathrm{m}$ and then thoroughly mixed with $<38 \mu \mathrm{m}$ corundum as an internal standard at $20 \mathrm{wt} \%$ for quantification of amorphous phase(s). Phase identification was carried out using the DiffracPlus EVA software (Version 3.0, Bruker, Billerica, MA, USA) with application of the Crystallography Open Database (COD). Quantitative phase analysis was performed using the Rietveld method $[14,15]$ with the aid of the computer program TOPAS (Version 4.2, Bruker, Billerica, MA, USA).

Due to the complex mineralogy and significant amounts of amorphous phases present within the natural waste materials (as determined from XRD analysis), quantitative evaluation of minerals (QEM-SCAN; [16]) was carried out to gain further mineralogical information for comparison with the quantitative XRD mineralogy. Samples for QEM-SCAN analysis (by Bureau Veritas, Adelaide, Australia) were dry-ground to $<75 \mu \mathrm{m}$ and were made into cylindrical epoxy resin blocks (diameter: $\approx 2.5 \mathrm{~cm}$; thicknesses: $\approx 8 \mathrm{~mm}$ ) with the sample surface sides polished. Bulk sample assay was carried out by Levay and Co. Environmental Services, Adelaide, Australia.

Leached samples (carbon coated prior to SEM) were examined using scanning electron microscopy (Phillips XL30 field emission SEM, FEI, Hillsboro, OR, USA), with energy dispersive spectroscopy (EDS), using both backscattered and secondary electron modes. The operating voltage was set to $15 \mathrm{kV}$, or $20 \mathrm{kV}$ to observe heavier elements. EDS analyses were also conducted to obtain semi-quantitative elemental compositions.

$\mathrm{pH}$ and $\mathrm{E}_{\mathrm{h}}$ of leachates (collected after each four-weekly flush) were measured, using $\mathrm{Ag} / \mathrm{AgCl} \mathrm{pH}$ and $\mathrm{E}_{\mathrm{h}}$ electrodes (filling solutions: saturated $\mathrm{KCl}$ ) calibrated with standard $\mathrm{pH}$ buffers (provided by TPS, Brendale, Australia) and ORP standard solutions (provided by EUTECH Instruments, Singapore). All $\mathrm{pH}$ and $\mathrm{E}_{\mathrm{h}}$ measurements were completed within several hours of leachate collection. The measured $E_{h}$ values were converted to redox potentials against standard hydrogen electrode (SHE), which were then used for PHREEQC thermodynamic calculations (see text below) and calculation of ferric concentrations using the Nernst equation (Section 3.2.2).

Inductively-coupled plasma optical emission spectroscopy (ICP-OES; Optima 5300 V, Perkin Elmer, Waltham, MA, USA) analysis ( $\pm 10 \%$ analysis errors) was undertaken to obtain the concentration of major ions in the collected KLC leachates (filtered through $0.45 \mu \mathrm{m}$ syringe filters prior to analysis). Calibration solutions for the ICP-OES analysis were made from high-purity standards, i.e., single-element solutions at $1000 \mathrm{ppm}$ concentration in $2 \mathrm{wt} \%$ nitric acid. Calculations of mineral saturation indices were performed using the PHREEQC computer program [17] with the Lawrence Livermore National Laboratory database ("llnl.dat"), $\mathrm{E}_{\mathrm{h}}, \mathrm{pH}$, and solution chemistry (ICP-OES results) of leachates.

\section{Results and Discussion}

\subsection{KLC Tests Using Synthetic Waste}

\subsubsection{Leachate Chemistry}

The $\mathrm{pH}$ of leachate from the control KLC (Milli-Q water; Figure 2a) decreased from initially $\approx 4.5$ to below 3.0 at week 28 , whereas the $\mathrm{pH}$ of leachate from the KLC treated with lime-saturated water during weeks 1-4 (Milli-Q with lime-saturated water; Figure 2a) remained circum-neutral (6.5-8.1) up to week 60 and the leachates had an average alkalinity of $20 \mathrm{mg} \cdot \mathrm{CaCO}_{3} \cdot \mathrm{L}^{-1}$. Subsequently, the $\mathrm{pH}$ of leachate from this KLC dropped to $\mathrm{pH} 3.8$ at week 64, but a further cycle of watering/flushing with lime-saturated water restored the $\mathrm{pH}$ to near neutral, suggesting that additional alkalinity is needed to maintain near neutral leachate. 

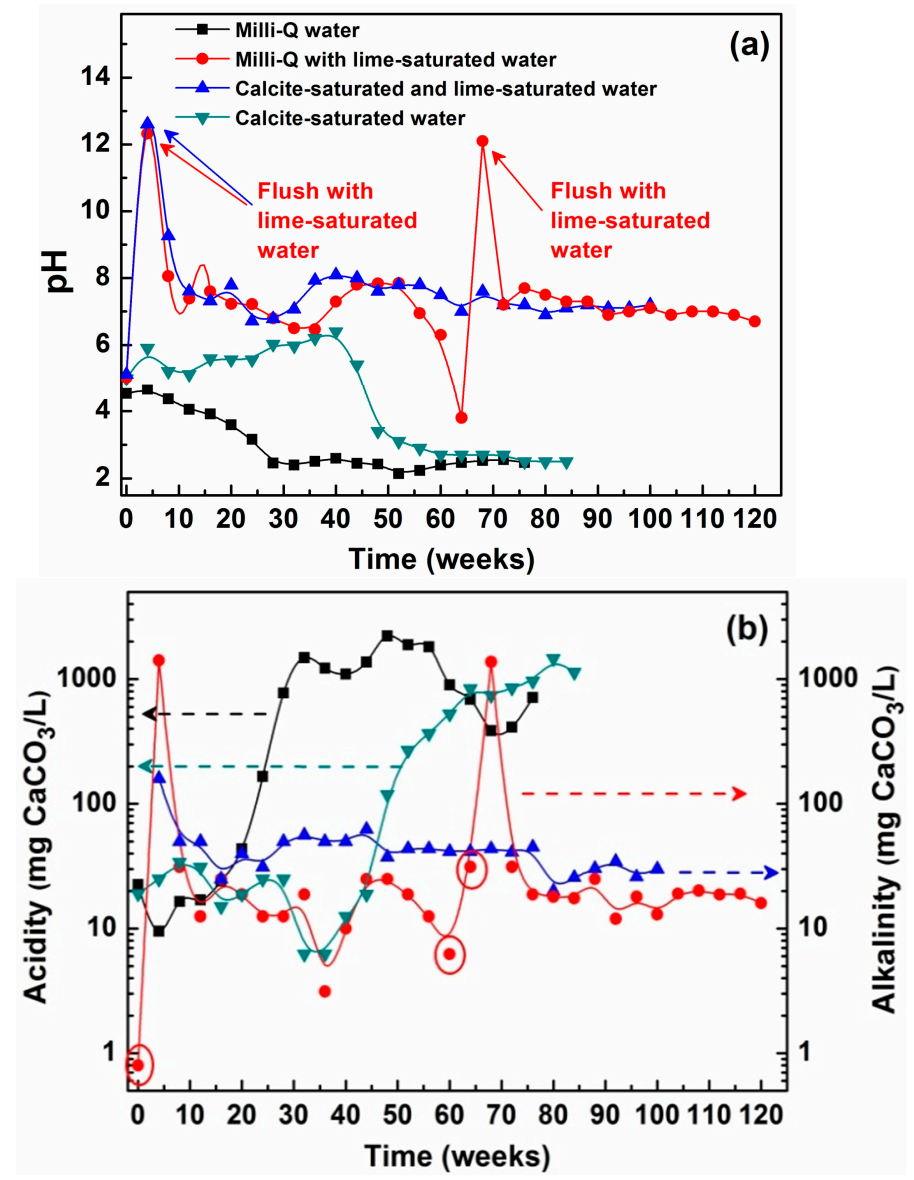

Figure 2. Characteristics of leachates from KLC tests using the synthetic waste: (a) $\mathrm{pH}$; (b) acidity/alkalinity (both on log scales). The legends and line colours in (a) also apply to (b). Note that the three circled data points in (b) represent acidity, rather than alkalinity.

Watering and flushing with calcite-saturated water throughout the entire leach process (Calcite-saturated water; Figure 2a), resulted in leachate $\mathrm{pH}$ in the range of 5.1-6.4 until week 40, after which the $\mathrm{pH}$ decreased sharply to 2.7. Prior to this rapid decrease in $\mathrm{pH}$, leachates had an average acidity of around $20 \mathrm{mg} \cdot \mathrm{CaCO}_{3} \cdot \mathrm{L}^{-1}$ (Figure $2 \mathrm{~b}$ ) despite the addition of calcite-saturated water. When calcite-saturated water was used for flushing and watering after application of the initial cycle of watering/flushing with lime-saturated water (calcite-saturated and lime-saturated water; Figure 2a), the $\mathrm{pH}$ of the leachate remained between 6.7 and 8.1 during almost two years of leaching. During this period, these leachates contained an excess of alkalinity of around $40 \mathrm{mg} \cdot \mathrm{CaCO}_{3} \cdot \mathrm{L}^{-1}$ (Figure $2 \mathrm{~b}$ ).

Together, these results suggest that to maintain long-term circum-neutral $\mathrm{pH}$ leachates, sufficient alkalinity must be added initially to obtain $\mathrm{pH} \geq 7$, and that this must be maintained by ongoing addition of low levels of alkalinity such as might be achieved by capping with a limestone cover. In the case of the synthetic waste used in these tests (maximum acidity of $\approx 2000 \mathrm{mg} \cdot \mathrm{CaCO}_{3} \cdot \mathrm{L}^{-1}$ ), initial treatment with lime-saturated water and subsequent watering/flushing with calcite-saturated solution (calcite-saturated and lime-saturated water, Figure 2a) were sufficient to provide circum-neutral $\mathrm{pH}$ conditions within the waste over 100 weeks to date.

\subsubsection{SEM Study}

SEM-EDS analysis indicates that all pyrite surfaces, except those from the Milli-Q water KLC, were covered to some degree with iron (oxy)hydroxide layers, regardless of leachate $\mathrm{pH}$ (Figure 3). Numerous discrete particles were observed on all pyrite surfaces, but with differences in compositional 
distribution between particles sampled from neutral and acidic leachate KLC tests. In the Milli-Q water KLC, potassium iron sulphate precipitates, probably K-jarosite, were also observed on the pyrite surfaces (Figure 3a, leachate $\mathrm{pH} 2.5$, week 76).

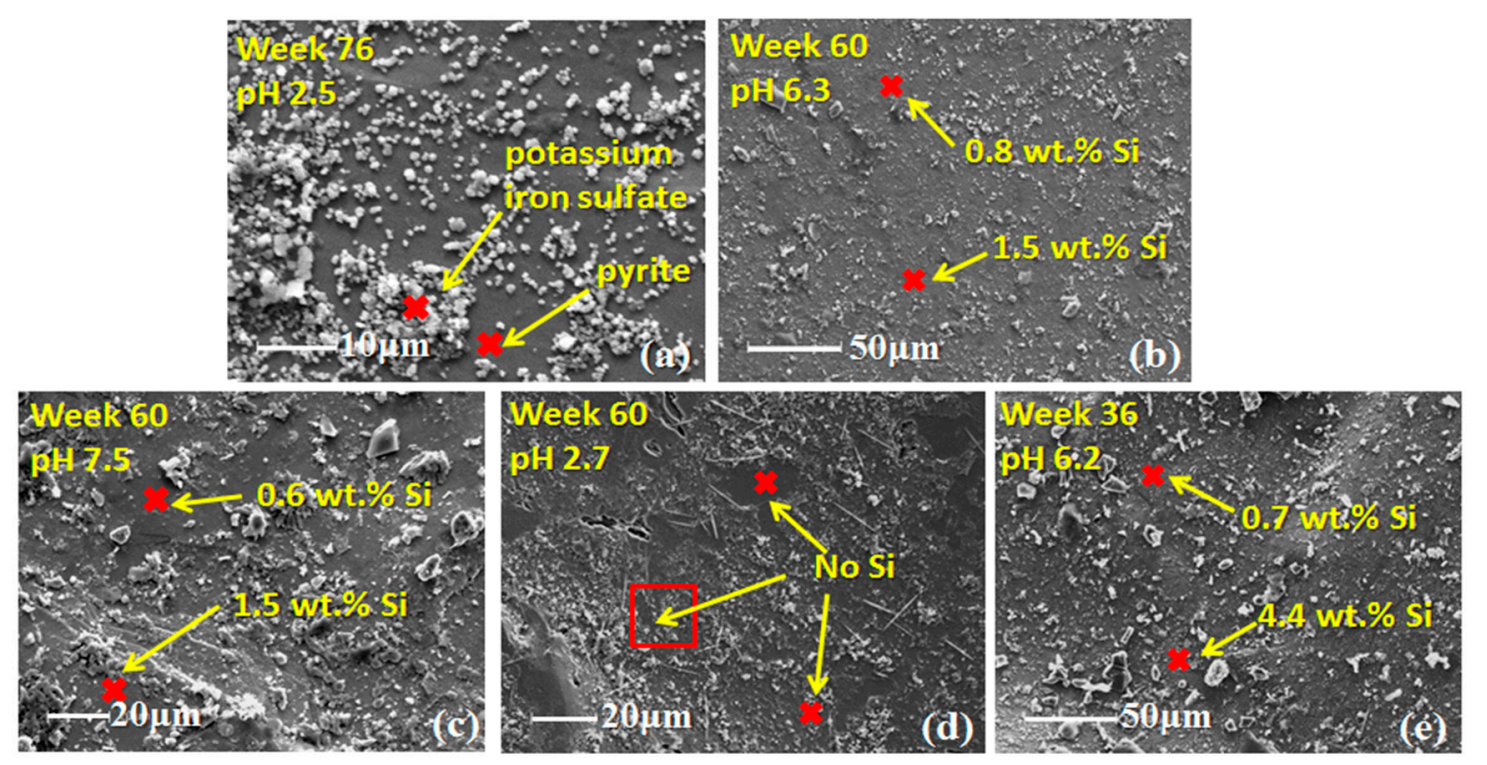

Figure 3. Secondary electron SEM images of samples collected from the four KLC tests containing synthetic waste. (a) Milli-Q; (b) Milli-Q with lime-saturated water; (c) calcite-saturated and lime-saturated water; (d,e) calcite-saturated water. Red crosses and the square in the images indicate EDS analysis areas. The potassium iron sulphate found on pyrite surfaces in (a) is likely to be potassium jarosite. The sample in (a) was collected immediately after the termination of the KLC experiment (i.e., at week 76). NB. The Si (silicate) is most likely derived from the dissolution of K-feldspar and/or chlorite.

When the leachate $\mathrm{pH}$ was around neutral, pyrite surface layers all contained measurable concentrations of $\mathrm{Si}$ (e.g., $\mathrm{pH}$ 6.3, 7.5, and 6.2 corresponding to Figure 3b-e). The range of composition (in wt \%) of these surface layers was 58.6-65.3 Fe, 32.1-36.9 O, 0.6-4.4 Si, 1.5-2.0 S, 0.4-0.8 Al, and $0.2-0.5 \mathrm{Mg}$. These large concentrations of $\mathrm{Fe}$ and $\mathrm{O}$, suggest that these layers are primarily iron (oxy)hydroxide doped with silicates (and maybe sulphur/sulphate). These observations are consistent with the proposition that the pyrite surfaces may be passivated by silicate-doped/stabilised iron (oxy)hydroxide layers [5,18-21]. The silicate present within these surface layers is most likely derived from dissolved silicates (K-feldspar and/or chlorite in the KLC tests) as the pyrite contained $<30 \mathrm{ppm}$ Si (Table S1, Supplementary Materials).

When leachate $\mathrm{pH}$ decreased to below 3.0, the surface iron (oxy)hydroxide layers were distinctly patchy, with regions that did not contain silicate (Figure 3d week 60 at pH 2.7 cf. Figure 3e week 36 at $\mathrm{pH}$ 6.2, both from calcite-saturated water KLC), and needle-like iron (oxy)hydroxide precipitates (goethite-like crystals; Figure 3d) developed on the pyrite surface (no passivation as $\mathrm{pH}$ was not maintained circum-neutral by this goethite-like surface layer). The elemental composition of the goethite-like layer is similar to those described above, except that it contained no $\mathrm{Si}, \mathrm{Al}$, or $\mathrm{Mg}$, and the morphology is distinctly different. This is in agreement with our recent research regarding pyrite dissolution in the presence/absence of added aqueous silicate [18], which demonstrated that surface passivation of pyrite occurs under circum-neutral $\mathrm{pH}$ conditions by the formation of silicate-doped surface iron (oxy)hydroxide layers. The presence of silicates within the iron (oxy)hydroxide layer is proposed to inhibit transformation of the amorphous surface passivating layers to crystalline goethite, which does not provide passivation [18]. 


\subsection{KLC Tests Using Natural Mine Wastes}

\subsubsection{Sample Characterisation}

All natural samples were sourced from Western Australia's Pilbara region iron ore waste rocks. Net acid generation (NAG) results (Table 3) indicate that sample \#1 is a PAF material and samples \#2 and \#3 (denoted as PAF, NAF1, and NAF2, respectively, hereafter) are NAF with high acid neutralisation capacities (ANC), particularly NAF1 (ANC of $938 \mathrm{~kg} \cdot \mathrm{H}_{2} \mathrm{SO}_{4} \cdot \mathrm{t}^{-1}$ ). Based on the dolomite and calcite contents obtained from quantitative XRD and QEM-SCAN analyses of samples prior to the start of KLC experiments (Table 4), the ANC of NAF2 is calculated to be 560 and $400 \mathrm{~kg} \cdot \mathrm{H}_{2} \mathrm{SO}_{4} \cdot \mathrm{t}^{-1}$, respectively. ANC measured using the modified Sobek ANC test [22] or calculated from inorganic carbon analysis (391 and $379 \mathrm{~kg} \cdot \mathrm{H}_{2} \mathrm{SO}_{4} \cdot \mathrm{t}^{-1}$ respectively; Table 3) is significantly less than that based on the dolomite and calcite content obtained from XRD, but close to $400 \mathrm{~kg} \cdot \mathrm{H}_{2} \mathrm{SO}_{4} \cdot \mathrm{t}^{-1}$ based on the dolomite content measured by QEM-SCAN.

Table 3. Net acid generation and acid base accounting results for samples for the case study (units in $\mathrm{kg} \cdot \mathrm{H}_{2} \mathrm{SO}_{4} \cdot \mathrm{t}^{-1}$ unless stated otherwise).

\begin{tabular}{|c|c|c|c|c|c|c|c|c|}
\hline Sample & $\mathrm{ANC}^{1}$ & $\mathrm{ANC}^{2}$ & $\mathrm{NAG}_{7}{ }^{3}$ & MPA $^{5}$ & $\mathrm{MPA}^{* 6}$ & NAPP 7 & NAPP* 8 & $\begin{array}{l}\text { Geochemical } \\
\text { Classification }\end{array}$ \\
\hline$\# 1$ (PAF) & 2.4 & 0 & 125 & 123 & 118 & 121 & 116 & PAF \\
\hline \#2 (NAF1) & 938 & 984 & $/^{4}$ & 1.5 & 1.2 & -936 & -937 & NAF \\
\hline \#3 (NAF2) & 391 & 379 & / & 1.5 & 1.2 & -389 & -390 & NAF \\
\hline
\end{tabular}

${ }^{1}$ ANC by the modified Sobek test; refer to [12] for details of ANC calculation; ${ }^{2}$ ANC calculated from inorganic carbon content; ${ }^{3}$ Refer to [12] for details of NAG measurement/calculation; ${ }^{4} /:$ not applicable; ${ }^{5} \mathrm{MPA}=$ maximum potential acidity $=$ Total $\mathrm{S} \times 30.6 ;{ }^{6} \mathrm{MPA}^{*}=\mathrm{CRS} \times 30.6 ; \mathrm{CRS}=$ chromium reducible sulphur (reactive sulphide; Table 5$) ;{ }^{7} \mathrm{NAPP}=$ net acid producing potential $=\mathrm{MPA}-\mathrm{ANC} ;{ }^{8} \mathrm{NAPP}^{*}=\mathrm{MPA}^{*}-\mathrm{ANC}$.

Table 4. QEM-SCAN and QXRD results.

\begin{tabular}{|c|c|c|c|c|c|c|c|}
\hline \multicolumn{4}{|c|}{ QEM-SCAN (wt \%) } & \multicolumn{4}{|c|}{ QXRD (wt \%) } \\
\hline Phases & NAF1 & NAF2 & PAF & Phases & NAF1 & NAF2 & PAF \\
\hline Fe disulphides ${ }^{1}$ & 0.1 & 0.0 & 8.4 & Pyrite & - & - & 5 \\
\hline Hem/Mag & 4.3 & 3.7 & 1.0 & Hematite & 9 & 4 & - \\
\hline Geothite & 3.7 & 17.0 & 0.8 & Goethite & - & 18 & - \\
\hline Mn minerals ${ }^{2}$ & 0.0 & 11.0 & - & Magnetite & - & - & - \\
\hline Dolomite & 77.2 & 37.6 & - & Dolomite & 77 & 48 & - \\
\hline Ti minerals & 0.1 & 0.2 & 0.4 & Quartz & 2 & 1 & 42 \\
\hline Quartz & 3.8 & 3.6 & 42.0 & Calcite & - & 5 & - \\
\hline Feldspar & 0.8 & 0.5 & 17.4 & Nacrite & - & 7 & - \\
\hline Mica & 2.0 & 0.8 & 24.1 & Chlorite & - & 5 & - \\
\hline Clays & 1.6 & 3.1 & 1.4 & Muscovite & - & - & 22 \\
\hline Iron silicates ${ }^{3}$ & 4.1 & 19.0 & 3.5 & Microcline & - & - & 4 \\
\hline Other silicates & 1.9 & 2.4 & 0.5 & Lizardite & - & - & 3 \\
\hline Others & 0.4 & 1.1 & 0.3 & Amorphous 4 & 12 & 12 & 24 \\
\hline Total & 100 & 100 & 100 & Total & 100 & 100 & 100 \\
\hline
\end{tabular}

1 Includes iron disulphides and intergrowths of iron disulphides and iron silicates; ${ }^{2}$ includes pyrolusite, cryptomelane, pyroxmangite, manganite, and any other manganese minerals; ${ }^{3}$ includes chlorites, amphibole, serpentine, pyroxene, and intergrowths of silicates with iron oxides; ${ }^{4}$ wt $\%$ of amorphous phase in each sample was obtained by addition of corundum at $20 \mathrm{wt} \%$ as an internal standard.

Both QEM-SCAN and quantitative XRD analyses generally resulted in similar major mineral phase content, except that relatively large amounts of amorphous phase(s) were indicated by quantitative XRD analysis. Note: QEM-SCAN cannot distinguish crystalline from amorphous phases. In some cases, the wt $\%$ of minerals obtained from the two types of analyses were in disagreement. For instance, QEM-SCAN analysis resulted in $8.4 \mathrm{wt} \%$ Fe disulfides (pyrite as indicated by XRD analysis) in the 
natural PAF waste, while quantitative XRD only indicated $5 \mathrm{wt} \%$ pyrite. Based on chromium reducible sulphur (CRS; [23]) analysis (Table 5), the pyrite content was found to be $7.2 \mathrm{wt} \%$ in the natural PAF waste (almost double the wt $\%$ of pyrite in the synthetic waste), suggesting that pyrite content by XRD may be underestimated.

Table 5. Bulk assays and carbon/sulphur analysis of natural PAF and NAF waste rocks (ppm).

\begin{tabular}{|c|c|c|c|c|c|c|c|c|c|c|c|c|}
\hline Sample & $\mathrm{Al}$ & As & $\mathrm{Au}$ & B & $\mathrm{Ba}$ & $\mathrm{Be}$ & $\mathbf{B i}$ & $\mathrm{Ca}$ & $\mathrm{Cd}$ & Co & $\mathrm{Cr}$ & $\mathrm{Cu}$ \\
\hline PAF & 55,100 & 114 & $<5$ & 23 & 38 & 4 & $<5$ & 80 & 3 & 15 & 115 & 64 \\
\hline NAF1 & 22,600 & $<5$ & $<5$ & 108 & 34 & $<0.5$ & $<5$ & 214,000 & $<2.5$ & $<2.5$ & 17 & $<5$ \\
\hline NAF2 & 34,000 & 19 & $<5$ & 79 & 290 & 1 & $<5$ & 92,000 & $<2.5$ & 13 & 27 & 37 \\
\hline Detection limit & 10 & 5 & 5 & 5 & 5 & 0.5 & 5 & 25 & 2.5 & 2.5 & 2.5 & 5.0 \\
\hline Sample & $\mathrm{Fe}$ & K & La & $\mathbf{L i}$ & $\mathrm{Mg}$ & Mn & Mo & $\mathrm{Na}$ & $\mathrm{Ni}$ & $\mathbf{P}$ & $\mathbf{P b}$ & $\mathrm{Sb}$ \\
\hline PAF & 61,600 & 28,400 & 33 & 43 & 3900 & 40 & $<5$ & $<50$ & 49 & 256 & $<5$ & $<5$ \\
\hline NAF1 & 29,700 & 1300 & 3.5 & 22 & 113,000 & 430 & $<5$ & 302 & $<2.5$ & 52 & $<5$ & $<5$ \\
\hline NAF2 & 17,500 & 1700 & 27 & 93 & 45,300 & 27,800 & $<5$ & 824 & 45 & 264 & 5.5 & $<5$ \\
\hline Detection limit & 5 & 50 & 2.5 & 2.5 & 25 & 5 & 5 & 50 & 2.5 & 25 & 5 & 5 \\
\hline Sample & Se & Si & Sn & $\mathrm{Sr}$ & $\mathrm{Ti}$ & $\mathbf{U}$ & $\mathrm{V}$ & $\mathbf{W}$ & $\mathrm{Zn}$ & $\mathrm{Zr}$ & $\mathrm{Cl}$ & $F$ \\
\hline PAF & $<5$ & 269,000 & 12 & 45 & 1091 & 137 & 75 & $<5$ & 50 & 114 & $<60$ & 548 \\
\hline NAF1 & 5.5 & 59,900 & 29 & 50 & 384 & 64 & 14 & $<5$ & 11 & 33 & $<60$ & 738 \\
\hline NAF2 & $<5$ & 59,700 & 22 & 98 & 565 & 333 & 36 & $<5$ & 36 & 53 & $<60$ & 1627 \\
\hline Detection limit & 5 & 25 & 5 & 2.5 & 5 & 50 & 5 & 5 & 5 & 5 & 60 & 100 \\
\hline Sample & Total S & \multicolumn{2}{|c|}{$\mathrm{S}_{\mathrm{CRS}}$} & \multicolumn{3}{|c|}{ Total C } & \multicolumn{3}{|c|}{ Total organic C } & \multicolumn{3}{|c|}{ Total inorganic C } \\
\hline PAF & 40,300 & \multicolumn{2}{|c|}{38,500} & \multicolumn{3}{|c|}{53,400} & \multicolumn{3}{|c|}{53,400} & \multicolumn{3}{|c|}{0} \\
\hline NAF1 & 500 & \multicolumn{2}{|c|}{400} & \multicolumn{3}{|c|}{119,200} & \multicolumn{3}{|c|}{1100} & \multicolumn{3}{|c|}{118,100} \\
\hline NAF2 & 500 & \multicolumn{2}{|c|}{400} & \multicolumn{3}{|c|}{46,500} & \multicolumn{3}{|c|}{1000} & \multicolumn{3}{|c|}{45,500} \\
\hline
\end{tabular}

Comparison of quantitative XRD (Table 4), bulk assays and carbon/sulphur analysis results (Table 5) suggests that the amorphous phase(s) are possibly iron silicates, which were also found in the QEM-SCAN analysis, and organic matter (indicated by the presence of significant concentrations of organic carbon, especially in the natural PAF waste), possibly originating from shales associated with iron ore deposits in the Pilbara region of Western Australia [24]. The concentrations of total inorganic carbon are generally in agreement with the $\mathrm{wt} \%$ of dolomite and calcite from the quantitative XRD analysis.

\subsubsection{Leachate Chemistry}

The addition of lime ( $2 \mathrm{wt} \%$ blended) to the natural PAF waste resulted in only short-term retardation in $\mathrm{pH}$ decrease, with leachate $\mathrm{pH}$ of $<3$ observed after 12 weeks (Figure 4a). Similarly, the addition of a top cover of NAF2 waste $(\approx 40 \mathrm{wt} \%$ dolomite; Table 4$)$ in addition to lime blending resulted in circum-neutral $\mathrm{pH}$ for several weeks only. The NAF1 cover $(\approx 80 \mathrm{wt} \%$ dolomite; Table 4$)$ combined with $2 \mathrm{wt} \%$ blended lime resulted in neutral $\mathrm{pH}$ leachate up to 24 weeks; although leachate $\mathrm{pH}$ and acidity (still negligible at only $\approx 0.02 \mathrm{~kg} \cdot \mathrm{H}_{2} \mathrm{SO}_{4} \cdot \mathrm{t}^{-1}$ at week 36) thereafter decreased and increased, respectively. However, the addition of lime in combination with a dolomite-containing cover (NAF1 or NAF2), to date, resulted in a marked reduction in leachate acidity, more so than lime by itself (Figure $4 \mathrm{~b}$ ), with cumulative acidities of NAF-covered PAF wastes of $0.3 \%$ (NAF1) and $6.6 \%$ (NAF2) of that of the lime-only natural PAF waste KLC after 36 weeks. The lack of significant acidity even when leachate $\mathrm{pH}$ was acidic suggests that the concentration of toxic/heavy metals (e.g., $\mathrm{Pb}, \mathrm{Zn}$ ) is also likely to be significantly reduced, consistent with ICP-OES measurements (Table S2, Supplementary Materials). 

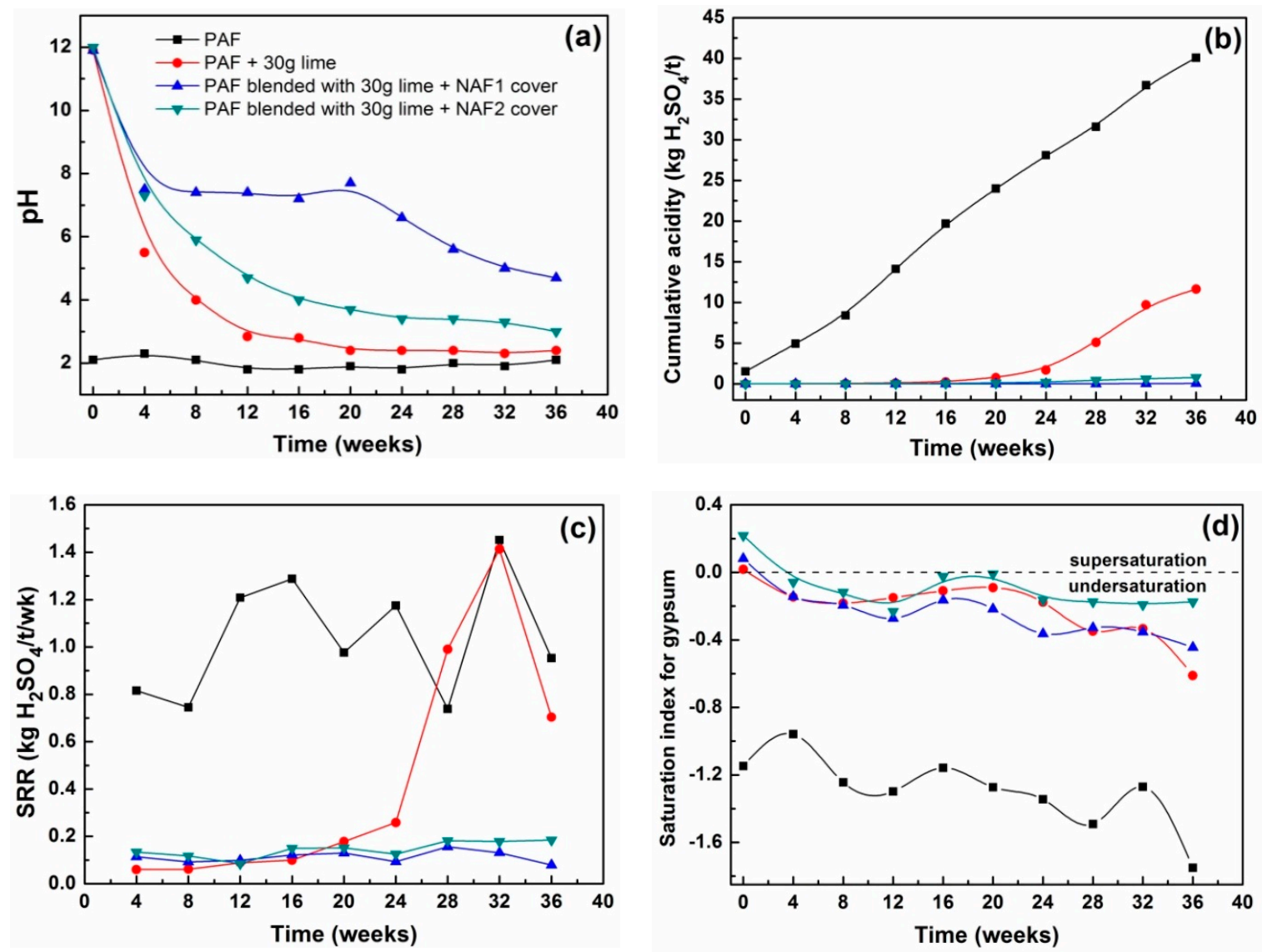

Figure 4. Leachate chemistry (a) $\mathrm{pH}$; (b) cumulative acidity; (c) sulphate release rate; and (d) gypsum saturation index from natural waste KLC tests. Cumulative acidity and SSR are normalised to per tonne of PAF. Figure legend for $(\mathbf{a})$ is common to $(\mathbf{b}-\mathbf{d})$.

Moreover, the addition of lime plus a dolomite-containing NAF cover also substantially reduced the rate of pyrite oxidation, as evidenced by the greatly reduced sulphate release rates (SRR; Figure 4c). This reduction in pyrite dissolution rate is also observed for the KLC containing lime but with no NAF cover up to 24 weeks. Solution speciation calculations suggest that this reduction in SRR is real and not a result of precipitation of sulphate within the KLC, with the gypsum saturation index indicating under-saturation for all but the initial week zero flush (Figure $4 \mathrm{~d}$ ).

These reduced pyrite oxidation rates may be due to the very low predicted concentration of total ferric ions in the leachates as compared to the natural PAF waste KLC leachate with no alkaline amendment. These concentrations have been calculated using ICP-OES results, $\mathrm{E}_{\mathrm{h}}$ of leachates (both given in Table S2, Supplementary Materials), and the Nernst equation (Equation (3); [25,26]) and are shown in Figure 5. The reaction rate between pyrite and ferric iron was observed by Moses et al. [27] to be one to two orders of magnitude greater than between pyrite and dissolved $\mathrm{O}_{2}$ in the $\mathrm{pH}$ range of 2-9. Where lime has been added with no NAF cover, ferric iron concentrations were probably too low to play a significant role in pyrite oxidation prior to week 16. The faster oxidation of pyrite (as suggested by SSR in Figure 4c) in the natural PAF waste KLC (no alkaline amendment) over the entire 36 weeks resulted in lower $\mathrm{pH}$, greater $\mathrm{E}_{\mathrm{h}}$, and greater concentration of ferric ion, which, in turn, accelerates the oxidative dissolution of pyrite.

$$
\mathrm{E}=0.67+(0.059 \times \log [\mathrm{FeIII}] /[\mathrm{FeII}])
$$




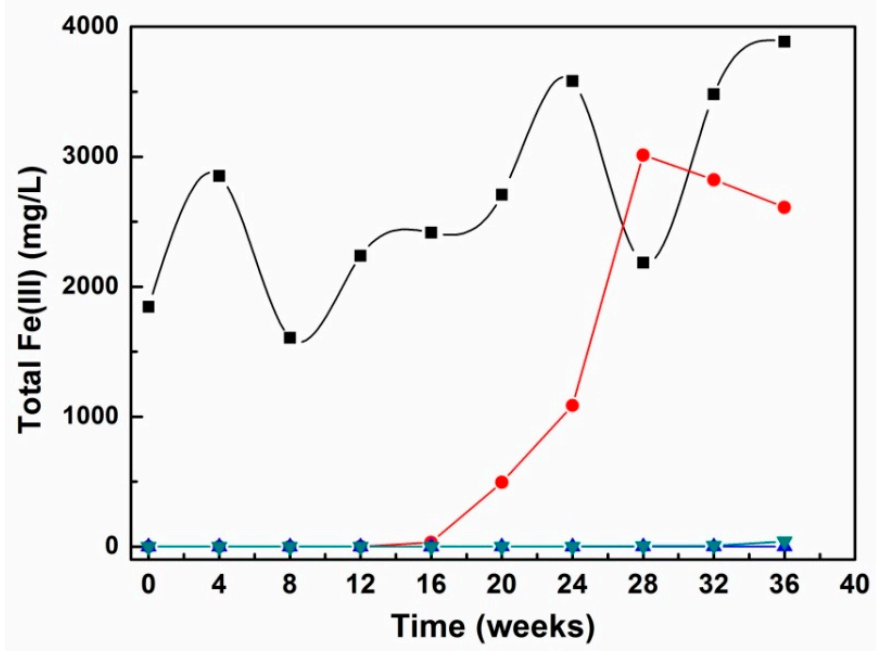

Figure 5. The concentration of total ferric iron in leachates from KLC tests using the natural mine wastes. See Figure 4a for legend.

Table 6 shows the amount of acidity generated from pyrite oxidation in each KLC based on leachate sulphur concentrations. The amount of acidity generated during the 36 weeks of testing is between $16 \%$ and $57 \%$ of the total alkalinity added by lime addition. Thus, the acidic leachate $\mathrm{pH}$ suggests that there may be preferential flow paths in the lime-amended KLC resulting in ineffective contact of the lime with leachate.

Table 6. Acidity and alkalinity balance (units all converted to $\mathrm{kg} \mathrm{H}_{2} \mathrm{SO}_{4}$ per tonne of PAF, for ease of comparison) and leachate $\mathrm{pH}$ from natural waste KLC tests at 36 weeks.

\begin{tabular}{ccccc}
\hline Sample & $\begin{array}{c}\text { Total Acid } \\
\text { Generated }^{\mathbf{1}}\end{array}$ & $\begin{array}{c}\text { Lime } \\
\text { Added }\end{array}$ & $\begin{array}{c}\text { Residual } \\
\text { Calciumin Lime }\end{array}$ & pH \\
\hline Natural PAF & 38.6 & 0 & 0 & 2.1 \\
Natural PAF + lime & 15.7 & 27.4 & 25.5 & 2.4 \\
Natural PAF + lime+ NAF1 & 4.3 & 27.4 & 24.5 & 4.7 \\
Natural PAF + lime +NAF2 & 5.5 & 27.4 & 24.1 & 3.0 \\
\hline
\end{tabular}

${ }^{1}$ Cumulative acidity calculated from ICP-OES sulphur concentrations (Table S2, Supplementary Materials) in leachates; ${ }^{2}$ Total added lime less total dissolved lime calculated from ICP-OES calcium concentrations in leachates.

\subsection{The Effectiveness of Passivation Strategies in the Treatment of Synthetic and Natural PAF Wastes}

For the synthetic mine waste investigated, the initial watering (between weeks 1-3) and flushing (at week 4 ) with lime-saturated solution (i.e., addition of $\approx 2.38 \mathrm{~g}$ of lime from three watering and one flushing, assuming ambient temperature lime solubility of $\approx 1.7 \mathrm{~g} \cdot \mathrm{L}^{-1}$ ) maintained circum-neutral $\mathrm{pH}$ in leachates for over one year without application of additional alkalinity (Milli-Q with lime-saturated water, Figure 2a), and for 100 weeks to date when subsequently watered/flushed with calcite-saturated water (calcite-saturated and lime-saturated water, Figure 2a). Application of the same methodology to the natural PAF waste (containing some 10-fold greater acidity; Figure 6) is unlikely to maintain circum-neutral $\mathrm{pH}$, as the addition of $30 \mathrm{~g}$ lime (i.e., a ten-fold increase in the use of lime, in comparison to flushing with lime-saturated water) maintained circum-neutral $\mathrm{pH}$ for several weeks only. This suggests that the successful passivation methodology used for the synthetic waste is applicable to PAF wastes with peak acidities equivalent to or below the alkalinity of saturated lime solution ( $\approx 2000 \mathrm{mg} \cdot \mathrm{CaCO}_{3} \cdot \mathrm{L}^{-1}$; Figure 6). Further testing would be required to assess the efficacy of the approach for passivating wastes with peak acidities between 2000 and $20,000 \mathrm{mg} \cdot \mathrm{CaCO}_{3} \cdot \mathrm{L}^{-1}$. 


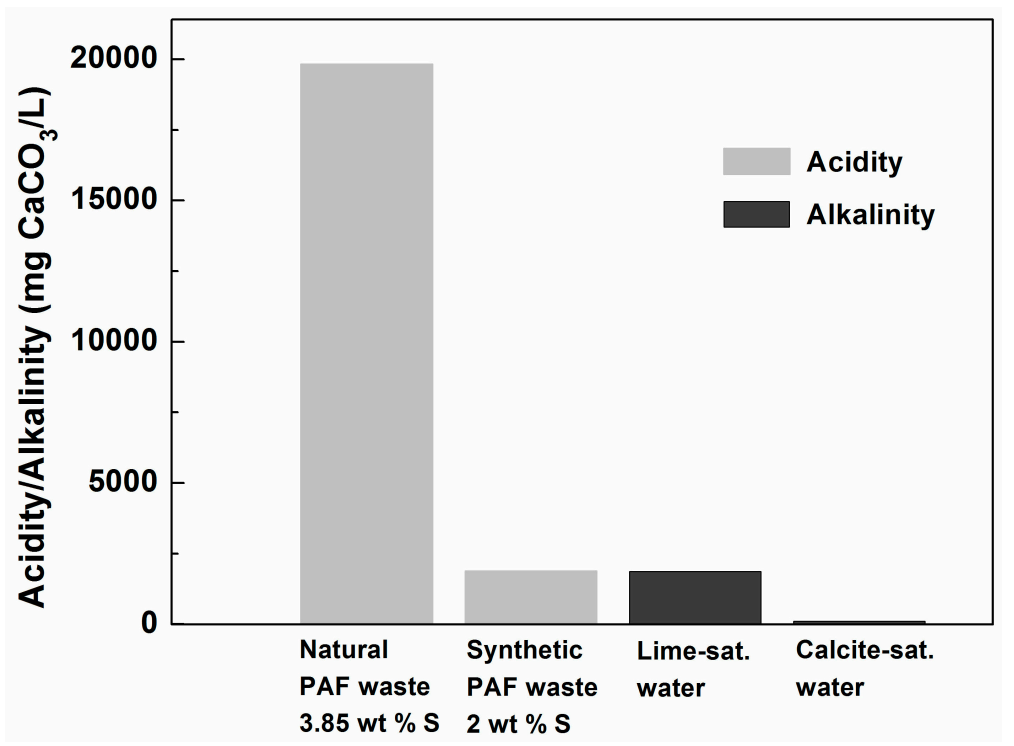

Figure 6. Peak leachate acidities from KLC tests for the natural and synthetic PAF wastes, alongside alkalinities available from saturated lime and calcite solutions.

Although the addition of $30 \mathrm{~g}$ lime to the natural PAF waste was not able to maintain near neutral $\mathrm{pH}$ in the long term, as required for establishment of pyrite surface passivating layers, the acidity generated was still greatly reduced as compared to watering/flushing with Milli-Q water only (Figure $4 \mathrm{~b}$ ). The use of two different natural NAF covers, especially the NAF1 cover, further reduced the acidity generated to negligible quantities to date (36 weeks, $<0.8$ and $<0.04 \mathrm{~kg} \cdot \mathrm{H}_{2} \mathrm{SO}_{4} \cdot \mathrm{t}^{-1}$ cumulative acidities for the two KLC tests with NAF2 and NAF1 covers, Figure 4b). The KLC tests using natural PAF and NAF materials (with lime addition) will be continued to see if reduced oxidation rates and leachate acidities will be maintained in the longer term, as relevant for practical field AMD applications. If this proves to be the case, the addition of smaller, more economically-feasible amounts of lime, together with application of NAF wastes as top covers, could be trialled as a potential sustainable AMD mitigation strategy for the management of highly reactive natural PAF wastes as encountered here.

\section{Conclusions and Implications}

We have investigated the application of added alkalinity in the form of saturated lime and calcite water, and lime and limestone (calcite and dolomite) to reduce the acid generation rate, through pyrite surface passivation, of both synthetic and natural mine wastes using laboratory-scale KLC tests. The results suggest that under these conditions, pore water $\mathrm{pH}$ needs to be kept near neutral with a slight excess of alkalinity for successful pyrite passivation.

For the synthetic mine waste (peak acidity $\approx 2000 \mathrm{mg} \cdot \mathrm{CaCO}_{3} \cdot \mathrm{L}^{-1}$ ), the initial application of lime-saturated water alone (watering/flushing with Milli-Q water, thereafter) resulted in the maintenance of circum-neutral $\mathrm{pH}$ (favourable for the formation and maintenance of pyrite surface passivation) up to 60 weeks. Circum-neutral $\mathrm{pH}$ was achieved and maintained up to 100 weeks (to date) through initial application of lime-saturated water and ongoing treatment with calcite-saturated water (low alkalinity input). These results suggest that for a moderately reactive PAF waste such as our synthetic waste, treatment with low levels of lime at the time of waste rock emplacement (i.e., equivalent to lime-saturated water treatment), combined with capping of the waste using limestone-containing materials (i.e., equivalent to calcite-saturated water treatment), may provide the conditions to both establish and maintain surface passivating layers on pyrite. This would greatly diminish the rate of acid generation and metal dissolution from within such wastes.

For the highly reactive natural PAF waste (peak acidity $\approx 20,000 \mathrm{mg} \cdot \mathrm{CaCO}_{3} \cdot \mathrm{L}^{-1}$ ), treatment with lime blending $(2 \mathrm{wt} \%)$ into the PAF waste and addition of limestone-containing wastes as top covers 
were inadequate for maintenance of pyrite passivation, but did successfully delay the onset and extent of acid generation (and toxic/heavy metals release; Table S2, Supplementary Materials). Based on these results, the amount of lime required to maintain the $\mathrm{pH}$ at or above 7 in these types of wastes until pyrite passivation can be achieved is likely to be cost prohibitive. Nevertheless, the addition of lime combined with a cover containing up to $80 \%$ dolomite, substantially reduced KLC leachate acidity by approximately 300 -fold relative to lime addition alone. Results suggest that the observed reduction in acidity generation is due to elimination of ferric iron, resulting in much slower pyrite oxidation and commensurate reduction in acid generation rate.

These outcomes, if maintained in the longer term, may mean that treatment of reactive PAF wastes in this way, combined with other control measures (e.g., construction of waste rock emplacements using layered and compacted methods), could substantially reduce or eliminate acid and metal loads in mine drainage. This highlights to industry the potential for the beneficial use of on-site neutralising waste materials and/or lithologies for cost-effective AMD mitigation, and reiterates the importance of comprehensive mineralogical surveys of these materials during dump planning and construction to assess their potential to offset requirements for sourcing off-site materials at high cost. Even incremental reductions in leachate $\mathrm{pH}$ and metal loads will translate to significant cost savings for AMD management at impacted mine sites worldwide.

While this study focused on the effect of extrinsic parameters/applications (e.g., lime blending, initial flushing with lime solution, NAF cover addition) on AMD generation from synthetic and natural mine wastes, the presence of microbes in these wastes may also play a role in AMD dynamics. For example, sulphur/sulphide-oxidising (e.g., Thiomicrospira and Sulfolobus $[28,29]$ ) and iron(II)-oxidising bacteria (e.g., Acidithiobacillus ferrooxidans [2,30]) are known to increase the oxidation of sulphide minerals, thus accelerating the AMD generation, while iron- and sulphate-reducing bacteria $[2,30,31]$ can potentially slow the AMD process. Investigation of the microbial communities in synthetic and natural waste KLC tests, treated with a range of organic amendments, is underway to more fully define the interplay of geochemistry and microbial actions and how this may be manipulated for more effective AMD control.

Supplementary Materials: The following are available online at www.mdpi.com/2075-163X/7/3/42/s1, Table S1: The composition (in ppm) of pyrite; Table S2: $\mathrm{E}_{\mathrm{h}}$ and elemental concentrations for the calculation of saturation index and ferric concentration using PHREEQC and the Nernst equation.

Acknowledgments: This project was supported by BHP Billiton Iron Ore (Australia), Teck (Canada) and the Australian Research Council (ARC) via ARC Linkage projects LP140100399 and LP130100568. Several anonymous reviewers are thanked for their feedback on the original manuscript.

Author Contributions: G.Q. performed the majority of experimental work, instrumental analysis and data interpretation, and also wrote the paper. A.R.G., R.S.C.S., R.C.S., and J.L. conceived and designed the experiments. A.R.G., R.S.C.S., R.C.S., and M.D.S. edited the paper. R.F., Y.L., and N.K. performed part of the work for kinetic leach column tests using the synthetic waste. Y.Z. carried out XRD analysis of natural waste samples used in this work. All authors contributed to paper writing, data interpretation and discussion.

Conflicts of Interest: The authors declare no conflict of interest.

\section{References}

1. Cheng, H.; Hu, Y.; Luo, J.; Xu, B.; Zhao, J. Geochemical processes controlling fate and transport of arsenic in acid mine drainage (AMD) and natural systems. J. Hazard. Mater. 2009, 165, 13-26. [CrossRef] [PubMed]

2. Johnson, D.B.; Hallberg, K.B. Acid mine drainage remediation options: A review. Sci. Total Environ. 2005, 338, 3-14. [CrossRef] [PubMed]

3. Gerson, A.R.; Li, J.; Smart, R.S.C.; Saint, C.P.; Short, M.D.; Schumann, R.C. Responsible management of acid mine wastes: Geochemical and microbiological resources. In Responsible Mining: Sustainable Practices in the Mining Industry; Jarvie-Eggart, M., Muga, H.E., Eds.; SME Publications: Littleton, CO, USA, 2014; pp. 519-542. 
4. Schumann, R.; Miller, S.; Rusdinar, Y.; Smart, R.; Kawashima, N.; Weissman, D. Towards understanding the chemistry of limestone mitigation of acid and metalliferous drainage in waste rock dumps-From laboratory to field experiments. In Proceedings of the Sixth Australian Workshop on Acid and Metalliferous Drainage, Burnie, Austalia, 15-18 April 2005; ACMER, Sustainable Minerals Institute (Brisbane, Australia): Burnie, Austalia, 2005.

5. Zeng, S.; Li, J.; Schumann, R.; Smart, R.S.C. Effect of ph and dissolved silicate on the formation of surface passivation layers for reducing pyrite oxidation. Comput. Water Energy Environ. Eng. 2013, 2, 50-55. [CrossRef]

6. Smart, R.S.C.; Ciccarelli, J.; Zeng, S.; Fan, R.; Li, J.; Kawashima, N.; Gerson, A.; Schumann, R. Assessment of acid neutralization rate from site rock for amd control. In Proceedings of the 10th International Conference on Acid Rock Drainage \& IWMA Annual Conference, Santiago, Chile, 21-24 April 2015.

7. Gitari, W.M.; Petrik, L.F.; Etchebers, O.; Key, D.L.; Iwuoha, E.; Okujeni, C. Passive neutralisation of acid mine drainage by fly ash and its derivatives: A column leaching study. Fuel 2008, 87, 1637-1650. [CrossRef]

8. Miller, S.D.; Stewart, W.S.; Rusdinar, Y.; Schumann, R.E.; Ciccarelli, J.M.; Li, J.; Smart, R.S.C. Methods for estimation of long-term non-carbonate neutralisation of acid rock drainage. Sci. Total Environ. 2010, 408, 2129-2135. [CrossRef] [PubMed]

9. Pérez-López, R.; Nieto, J.M.; de Almodóvar, G.R. Utilization of fly ash to improve the quality of the acid mine drainage generated by oxidation of a sulphide-rich mining waste: Column experiments. Chemosphere 2007, 67, 1637-1646. [CrossRef] [PubMed]

10. Smart, R.S.C.; Miller, S.D.; Stewart, W.S.; Rusdinar, Y.; Schumann, R.E.; Kawashima, N.; Li, J. In situ calcite formation in limestone-saturated water leaching of acid rock waste. Sci. Total Environ. 2010, 408, 3392-3402. [CrossRef] [PubMed]

11. Miller, S.; Andrina, J.; Richards, D. Overburden geochemistry and acid rock drainage scale-up investigations at the grasberg mine, Papua province, Indonesia. In Proceedings of the 6th ICARD, Cairns, Australia, 12-18 July 2003; pp. 111-121.

12. Smart, R.S.C.; Skinner, B.; Levay, G.; Gerson, A.; Thomas, J.; Sobieraj, H.; Schumann, R.; Weisener, C.; Weber, P.; Miller, S. ARD Test Handbook; AMIRA International: Aurora, CO, USA, 2002; Available online: http: / /www.amira.com.au/documents/downloads/P387AProtocolBooklet.pdf (accessed on 13 March 2017).

13. Davis, B.; Bourgeot, N.; Taylor, J. Using kinetic geochemical testwork to assist with mine planning, operations and post closure. In Proceedings of the Eighth Australian Workshop on Acid and Metalliferous Drainage, Adelaide, Australia, 29 April-2 May 2014; Miller, H., Preuss, L., Eds.; JKTechPty Ltd.: Adelaide, Australia, 2014; pp. 281-294.

14. Rietveld, H. Line profiles of neutron powder-diffraction peaks for structure refinement. Acta Crystallogr. 1967, 22, 151-152. [CrossRef]

15. Rietveld, H. A profile refinement method for nuclear and magnetic structures. J. Appl. Crystallogr. 1969, 2, 65-71. [CrossRef]

16. Qian, G.; Li, Y.; Gerson, A.R. Applications of surface analytical techniques in earth sciences. Surf. Sci. Rep. 2015, 70, 86-133. [CrossRef]

17. Parkhurst, D.L.; Appelo, C.A.J. Users's Guide to Phreeqc (Version 2)—A Computer Program for Speciation, Batch-Reaction, One-Dimensional Transport, and Inverse Geochemical Calculations; US Geological Society: Denver, CO, USA, 1999; pp. 1-326.

18. Fan, R.; Short, M.D.; Zeng, S.; Qian, G.; Li, J.; Schumann, R.; Kawashima, N.; Smart, R.S.C.; Gerson, A.R. The formation of surface passivating layers on pyrite for reduced acid rock drainage. Environ. Sci. Technol. 2017. submitted.

19. Schumann, R.; Kawakami, N.; Li, J.; Miller, S.; Smart, R.S.C.; Stewart, W. Passivating Surface Layer Formation on Pyrite in Neutral Rock Drainage. In Proceedings of the Securing the Future 8th ICARD, Skellefteå, Sweden, 23-26 June 2009; pp. 1-10. Available online: http:/ / search.ror.unisa.edu.au/media/researcharchive/open/ 9915910957201831/53108999780001831 (accessed on 13 March 2017).

20. Miller, S.; Schumann, R.C.; Smart, R.S.C.; Rusdinar, Y. ARD Control by Limestone Induced Armouring and Passivation of Pyrite Minerals Surfaces. In Proceedings of the Securing the Future and 8th ICARD, Skellefteå, Sweden, 23-26 June 2009; p. 10. Available online: http:/ / www.inap.com.au/documents/Stuart_Miller_ B6_T4_ARD-Control-by-Limestone-Induced-Armouring-and-Passivation-of-Pyrite-Min.pdf (accessed on 13 March 2017). 
21. Gerson, A.; Smart, R.S.C.; Li, J.; Kawashima, N.; Fan, R.; Zeng, S.; Schumann, R.; Levay, G.; Dielemans, P.; Mc Latchie, P.; et al. Mineralogy of mine site neutralising materials: A missing link in amd control planning. In Proceedings of the Eighth Australian Workshop on Acid and Metalliferous Drainage, Adelaide, Australia, 29 April-2 May 2014; Miller, H., Preuss, L., Eds.; JKTech Pty Ltd.: Adelaide, Australia, 2014; pp. 313-324.

22. Sobek, A.A.; Schuller, W.A.; Freeman, J.R.; Smith, R.M. Field and Laboratory Methods Applicable to Overburdens and Minesoils; EPA-600/2-78-054; U.S. Environmental Protection Agency: Cincinnati, OH, USA, 1978; pp. 47-50.

23. Schumann, R.; Stewart, W.; Miller, S.; Kawashima, N.; Li, J.; Smart, R. Acid-base accounting assessment of mine wastes using the chromium reducible sulfur method. Sci. Total Environ. 2012, 424, 289-296. [CrossRef] [PubMed]

24. Brocks, J.J.; Summons, R.E.; Buick, R.; Logan, G.A. Origin and significance of aromatic hydrocarbons in giant iron ore deposits of the late archean hamersley basin, Western Australia. Org. Geochem. 2003, 34, 1161-1175. [CrossRef]

25. Hiroyoshi, N.; Miki, H.; Hirajima, T.; Tsunekawa, M. Enhancement of chalcopyrite leaching by ferrous ions in acidic ferric sulfate solutions. Hydrometallurgy 2001, 60, 185-197. [CrossRef]

26. Li, Y.; Wei, Z.; Qian, G.; Li, J.; Gerson, A. Kinetics and mechanisms of chalcopyrite dissolution at controlled redox potential of $750 \mathrm{mv}$ in sulfuric acid solution. Minerals 2016, 6, 83. [CrossRef]

27. Moses, C.O.; Kirk Nordstrom, D.; Herman, J.S.; Mills, A.L. Aqueous pyrite oxidation by dissolved oxygen and by ferric iron. Geochim. Cosmochim. Acta 1987, 51, 1561-1571. [CrossRef]

28. Bond, P.L.; Banfield, J.F. Design and performance of rrna targeted oligonucleotide probes for in situ detection and phylogenetic identification of microorganisms inhabiting acid mine drainage environments. Microb. Ecol. 2001, 41, 149-161. [PubMed]

29. Brierley, C.L.; Le Roux, N.W. Bacterial leaching. CRC Crit. Rev. Microbiol. 1978, 6, 207-262. [CrossRef]

30. Sánchez-Andrea, I.; Rodríguez, N.; Amils, R.; Sanz, J.L. Microbial diversity in anaerobic sediments at río tinto, a naturally acidic environment with a high heavy metal content. Appl. Environ. Microbiol. 2011, 77, 6085-6093. [CrossRef] [PubMed]

31. Morales, T.A.; Dopson, M.; Athar, R.; Herbert, R.B. Analysis of bacterial diversity in acidic pond water and compost after treatment of artificial acid mine drainage for metal removal. Biotechnol. Bioeng. 2005, 90, 543-551. [CrossRef] [PubMed] 